\title{
ANALISA KETERPADUAN PASAR KOPI DAN KARET INDONESIA
}

\author{
Ketut Sukiyono dan Sriyoto \\ Staf Pengajar Jurusan Sosial Ekonomi Pertanian Fak. Pertanian UNIB \\ Abstract
}

Processing coffe industry at Bengkulu city face with finacial, production technology and market information burdens,generally. Its later affect to the industrys' competitive advantage Commonly, the compettitve advantage was good, its showed by revenue-cost ratio about 1,26.

Key words ; Competitive advantage, coffe,industry

\section{PENDAHULUAN}

Prospek komoditi ini semakin menjanjikan karena bahan baku untuk pembuatan kopi bubuk merupakan komoditas unggulan daerah serta ketersediaannya berlimpah dalam menunjang pengembangan industri kecil kopi bubuk. Luas tanaman kopi di Propinsi Bengkulu sebesar 68.524 ha dengan produksi kopi bubuk mencapai 54.843 ton atau produktifitas rata-rata sebesar $0.80 \mathrm{~kg} / \mathrm{ha}$. Dari bahan baku tersebut mampu dihasilkan kopi bubuk dengan nilai produksi sebesar Rp.3 miliar lebih selama tahun 2003. Nilai produksi ini hanya sebagian dari produksi bahan baku yang ada,sedangkan sisanya diduga kuat diolah dan dipasarkan ke luar Propinsi Bengkulu. Namun penerimaan dari komoditi kopi diperkirakan akan terus meningkat sampai dengan 2010 mencapai Rp.58.232.000.000 jika kondisi idealnya terus dipertahankan (Hafsari, 2004; Juita, 2004 ). Apalagi bila semua bahan baku tersebut diolah menjadi kopi bubuk pada industri pengolahan lokal untuk memenuhi pangsa pasar yang telah ada sehingga memberikan nilai tambah yang lebih tinggi bagi perekonomian daerah secara keseluruhan.

Meskipun perkebunan kopi dan industri kecil kopi bubuk secara bersama-sama menjadi prioritas utama pembangunan industri kecil di Propinsi Bengkulu, namun perlu dipahami bahwa dalam sistem agribisnis (sub-sistem pengolahan) komoditas ini di Propinsi Bengkulu khusus pengolahan kopi bubuk di Kota Bengkulu secara umum mengalami permasalahan mulai keterbatasan permodalan, penguasaan teknologi produksi dan informasi pasar. Secara umum permasalahan komoditi kopi di hampir sebagian besar wilayah Indonesia menurut (Wardhani dan Herman, 200) disebabkan oleh pangsa produksi kopi mutu rendah (IV - VI), masih di atas 85\% 
dan kurang dari 15\% produksi kopi bermutu. Usaha ini juga didominasi oleh pengrajin tradisional berskala usaha kecil, yang dicirikan oleh volume produk-produk yang dihasilkan keadaan kualitas dan kuantitasnya mengalami ketidakpastian pasar dan mengalami fluktuasi harga yang besar. Hampir sebagian besar pengolahan kopi bubuk di Kota Bengkulu yang berbahan baku kopi robusta tidak mengalami perkembangan, malah cenderung statis, khususnya dalam ukuran usaha yang belum ekonomis.

Di pihak lain, karakteristik permintaan pasar komoditas tidak bersifat homogen, jika dibandingkan dengan pasar komoditas sector riil yang diasilkan oleh industri manufaktur, jasa dan perdagangan (Hayami dan Ruttan, 1984). Dengan sifat permintaan yang didominasi oleh skala usaha kecil-kecil tersebut, tidaklah mengherankan jika kebanyakan industri kecil kopi bubuk beroperasi secara tidak layak dan tidak ekonomis dengan tingkat produksi baik secara kuantitas maupun kualitas relatif rendah sehingga kepastian harga sulit untuk terwujud secara sempurna. Kondisi ini menyebabkan industri kecil kopi bubuk mengalami skala tidak ekonomis. Penyebab dari skala tidak ekonomis antara lain mismanajemen baik teknis maupun ekonomis, ketiadaan pekerja yang terampil, dan keburukan administrasi serta kondisi kelembagaan produksi maupun pasar yang terfrgamentasi. Padahal untuk dapat bersaing secara terbuka dengan produk sejenis penanganan proses produksi secara ekonomis dan efisien merupakan kunci utama meningkatan kinerja dan daya saing industri kecil kopi bubuk di Kota Bengkulu. Indikasi-indikasi mismanajemen dalam pengelolaan pengolahan kopi bubuk di Kota Bengkulu dapat dilihat dari aspek ekonomi dan finansial serta teknis. Menurut Coelli et al (1998) jika industri kecil kopi bubuk belum bekerja penuh, biaya rata-rata masih di atas biaya minimum, peningkatan produksi akan menyebabkan biaya rata mendekati biaya minimum. Sebaliknya jika industri kecil kopi bubuk berproduksi dengan biaya rata-rata diatas biaya minimum dan peningkatan produksi selalu disertai dengan peningkatan biaya yang lebih besar. Menurut Anwar (2002), dan Romdhon, (2004) aspek ini dapat diketahui dari seberapa besar proporsi biaya terhadap penerimaan yang diperoleh pihak manajemen. Jumlah pijaman yang besar akan memberikan insentif berusaha yang lebih besar sehingga mampu menghasilkan penerimaan dan sekaligus melunasi pinjaman .

Menurut Wardhani dan Herman, (2000) secara teknis pengelolaan yang baik diketahui dari dari sejauhmana alokasi dan ketersediaan input produksi seperti bahan baku kopi, bahan bakar, serta peralatan produksi secara sesuai dan tepat. Input produksi yang teralokasi secara baik juga dibutuhkan tenaga kerja untuk produksi dan manajemen yang tidak hanya berpengalaman tapi 
juga terampil. Keberhasilan perusahaan dalam mengelola aspek ini akan menghasilkan output bermutu yang diterima dengan harga tinggi di pasar konsumen. Oleh karena itu yang menarik untuk dikaji dalam penelitian ini adalah bagaimana daya saing industri kecil pengolahan kopi bubuk di kota Bengkulu

\section{METODE PENELITIAN}

Lokasi penelitian ditentukan secara sengaja (purposive) yaitu di Kota Bengkulu, yang sebagian besar berada di pusat perbelanjaan dan perekonomian yaitu Pasar Mingu dan Pasar Panorama, dimana terdapat fenomena aktual pada industri kecil kopi bubuk yang sehingga potensi dan peluang pengembangannya masih cukup besar. Penarikan contoh dilakukan secara sensus terhadap keseluruhan populasi yaitu 22 pengolahan kopi bubuk. Terutama responden yang memenuhi kriteria sebagai pengrajin dan sekaligus pemilik pengolahan kopi bubuk. Analisis dalam tulisan ini dilakukan secara deskriptif dengan menjelaskan seluruh aspek yang berkenaan dengan rasio penerimaan terhadap biaya pada industri kecil pengolahan kopi bubuk sehingga diperoleh gambaran jelas tentang daya saingnya di Kota Bengkulu.

\section{HASIL DAN PEMBAHASAN}

Komposisi biaya produksi yang merupakan akumulasi biaya tetap dan biaya variabel pada pengolahan kopi bubuk di Kota Bengkulu, menunjukkan bahwa sebagian besar biaya produksi di peruntukkan untuk operasional produksi. Biaya bahan baku utama memberikan kontribusi terbesar terhadap penggunaan biaya variabel, kemudian biaya tenaga kerja dan biaya bahan penolong (pembelian jagung) untuk kategori kopi bubuk biasa. Biaya bahan baku yang relative besar dipicu oleh tingginya harga beli kopi beras dari pedagang pengumpul dan petani kopi. Umumnya para pensuplai bahan baku berlokasi jauh pusat produksi kopi bubuk seperti di Kabupaten Kepahiang, Kabupaten Bengkulu Selatan, Kabupaten Kaur.

Tabel 1. Persentase Biaya Variabel Usaha Pengolahan Kopi Bubuk di Kota Bengkulu.

\begin{tabular}{clrr}
\hline No & \multicolumn{1}{c}{ Biaya Variabel } & Jumlah (Rp) & $\%$ \\
\hline 1 & Tenaga Kerja Pria & $19,792,969$ & 11.74 \\
2 & Tenaga Kerja Wanita & $4,767,188$ & 2.83 \\
3 & Bahan Baku Utama & $122,737,500$ & 72.78 \\
4 & Bahan Penolong & $13,602,500$ & 8.07 \\
5 & Bahan Bakar Kayu & $2,128,400$ & 1.26 \\
6 & Bahan Bakar Solar & 510,300 & 0.30 \\
7 & Kemasan & $5,100,709$ & 3.02 \\
\hline \hline
\end{tabular}

Analisa Keterpaduan Pasar Kopi dan Karet Indonesia. (Ketut Sukiyono, 109 Sriyoto) 
Aspek lain yang mendorong tingginya harga kopi karena harga kopi dunia juga mengalami peningkatan yang semula berkisar antara Rp.3.000 - Rp.4.000 saat penelitian berlangsung harga kopi mencapai kisaran Rp.6.000 - 8.000 untuk per kilogram kopi beras.Tingginya harga kopi beras ini juga di dorong oleh kelangkaan pasokan beras kopi karena sebagian besar pedagang pengumpul dan petani terutama di Kabupaten Bengkulu Selatan dan Kaur menjual kopi beras ke pedagang antara daerah yang berasal dari Propinsi Lampung.

Biaya penggunaan bahan bakar memberikan kontribusi relatif kecil terhadap biaya variabel. Namun persentase biaya bahan bakar kayu relatif lebih besar dibandingkan biaya bahan bakar solar. Penggunaan bahan bakar solar hanya diperuntukkan bagi mesin pengolahan kopi, sementara aktifitas produksi lainnya lebih banyak menggunakan bahan bakar kayu. Di satu sisi, kondisi ini memberikan penerimaan bagi pelkau usaha pengolahan kopi bubuk, karena kenaikan harga Bahan Bakar Minyak (BBM) belum memberikan dampak negatif siknifikan terhadap keberlanjutan usaha mereka di Kota Bengkulu. Di sisi lain, kelangkaan bahan bakar kayu dikhawatirkan akan terjadi mengingat munculnya hambatan suplai kayu karena gencarnya pelarangan eksploitasi kayu hutan yang sebagina besar merupakan bahan bakar utama industri kecil di Propinsi Bengkulu.

Komposisi biaya tenaga kerja menunjukkan bahwa penggunaan tenaga kerja pria lebih besar dibandingkan tenaga kerja wanita. Umumnya tenaga kerja pria terserap pada aktifitas pengoperasian mesin pengolahan, perendangan kopi dan jagung, pembersihan biji kopi dan jagung, sedangkan tenaga kerja wanita hanya terserap pada aktifitas pembersihan biji kopi dan jagung, sebagian perendangan serta pengemasan termasuk aktifitas pemasaran. Disamping volume kerja yang relatif besar, perbedaan juga disebabkan oleh perbedaan upah, dimana upah tenaga kerja pria relatif lebih besar ketimbang upah tenaga kerja wanita.

Biaya perawatan mesin dan biaya penyusutan mesin pengolahan merupakan biaya tetap dengan kontribusi terbesar. Artinya sebagian besar pemiliki pengolahan kopiu bubuk di Kota Bengkulu belum melakukan investasi baru terhadap peralatan produksi terutama mesin pengolahan . Rata-rata mesin pengolahan yang dimiliki telah berumur 11,4 tahun. Secara teoritis mesin pengolahan kopi tersebut telah mendekati bahkan melampaui umur ekonomisnya (ratarata umur mesin pengolahan kopi berkisar 9 - 11 tahun). Sehingga pengoperasiannya 
membutuhkan biaya perawatan mesin yang relatif besar mencapai $26,64 \%$ seperti terlihat pada Tabel 2.

Tabel 2. Persentase Biaya Tetap Usaha Pengolahan Kopi Bubuk di Kota Bengkulu.

\begin{tabular}{clrr}
\hline No & \multicolumn{1}{c}{ Biaya Tetap } & Jumlah $(\mathrm{Rp})$ & \multicolumn{1}{c}{$\%$} \\
\hline 1 & Alat Perendangan & 118,403 & 6.948172 \\
2 & Mesin Pengolahan & 348,401 & 20.44503 \\
3 & Ember Besar & 18,558 & 1.089003 \\
4 & Ember Kecil & 7,049 & 0.41363 \\
5 & Perawatan Mesin & 454,000 & 26.64186 \\
6 & Kebersihan & 138,000 & 8.098187 \\
7 & Keamanan & 300,000 & 17.60475 \\
8 & Retribusi & 300,000 & 17.60475 \\
9 & Timbangan & 14,891 & 0.873834 \\
10 & Tampi & 4,785 & 0.28078 \\
\hline & $\quad$ Total & $1,704,085$ & 100 \\
\hline
\end{tabular}

Aspek-aspek lain yang berhubungan dengan kinerja usaha pengolahan kopi tapi tidak berkaitan langsung dengan produksi antara lain aspek iklim usaha, aspek kelembagaan dan pemasaran. Tabel 2 biaya yang dikeluarkan oleh pemilik terutama biaya retribusi dan keamanan memberikan kontribusi yang sama yaitu $17,61 \%$ per bulan, meksipun belum dapat dikatakan bahwa iklim usaha pengolahan kopi di Kota Bengkulu kurang kondusif. Angka ini relatif lebih besar dari biaya yang berkaitan langsung dengan produksi, seperti biaya penyusutan alat perendangan yang hanya berkisar $6-7 \%$.

Hal lain yang harus dicermati berdasarkan hasil penelitian Romdhon (2004) pada industri kecil gula aren di Kabupaten Rejang Lebong menunjukkan bahwa persentase biaya tetap yang merupakan proksi investasi oleh pelaku usaha kecil relatif kecil. Kondisi yang sama ditunjukkan pada industri pengolahan kopi dimana persentase biaya tetap hanya berkisar $6-20$ persen saja, bandingkan dengan persentase biaya variabel hanya untuk biaya bahan baku yang mencapai $73 \%$.

Realitas ini memberikan implikasi bahwa sebagian besar penggunaan modal usaha oleh industri kecil hanya untuk kegiatan operasional produksi. Sementara komposisi modal yang digunakan untuk aktifitas investasi seperti pembelian peralatan baru relatif tidak ada, yang ditunjukkan oleh belum adanya peremajaan peralatan (mesin pengolahan ) meskipun telah melewati umur ekonomisnya. Pertanyaannya adalah kenapa hal ini dapat terjadi? berdasarkan temuan Romdhon (2004), Pearson, Bahri dan Gostch (2003) fenomena ini timbul karena 
sebagian besar permodalan mereka berasal dari modal sendiri. Kesulitan mengakses pinjaman modal dari lembaga keuangan terutama bank karena mereka tidak memenuhi kriteria layak pinjam 4C yang ditetapkan terutama agunan (jaminan) pinjaman. Kalaupun ada akses pinjaman dilakukan melalui lembaga keuangan non-formal seperti tengkulak/rentenir. Umumnya tingkat suku bunga yang dibebankan kepada peaku usaha lebih tinggi dari lembaga bank, dan bersifat mengikat, meskipun aksesnya relatif mudah (birokrasi yang sederhana/tidak ada).

Rata-rata produksi yang dihasilkan per bulan untuk semua industri pengolahan kopi mencapai $80 \mathrm{~kg}$ per bulan untuk jenis kopi bubuk biasa dengan campuran jagung dan kopi bubuk spesial (bubuk kopi murni) masing-masing dalam kemasan berbeda. Harga rata-rata untuk kopi biasa berkisar Rp. 6.000 - Rp.8.000 per kg dan kopi spesial berkisar Rp. 14.000 - Rp.16.000 per $\mathrm{kg}$. Meskipun persentase penggunaan biaya variabel untuk operasional lebih besar dibandingkan persentase biaya tetap untuk investasi, atau secara rata-rata total biaya mencapai kisaran 16 juta yang dikeluarkan namun secara umum pelaku usaha pengolahan kopi di Kota Bengkulu masih memperoleh profit (penerimaan) tiap bulannya seperti tertera pada Tabel 3.

\section{Tabel 3. Rata-rata Biaya Tetap, Biaya Variabel, dan Penerimaan Usaha Pengolahan Kopi Bubuk di Kota Bengkulu.}

\begin{tabular}{|c|c|c|}
\hline No & Komponen & Satuan (Rp) \\
\hline 1 & Biaya Tetap & $15,714,141.30$ \\
\hline 2 & Biaya Variabel & $158,789.76$ \\
\hline 3 & Biaya Total & $15,872,931.06$ \\
\hline 4 & Penerimaan & $2,205,016.77$ \\
\hline
\end{tabular}

Rata-rata indeks perbadingan penerimaan terhadap total biaya yang dikeluarkan mencapai 1,26. Hal ini bermakna bahwa keberlanjutan usaha ini masih dapat berkesinambungan ke depan. Namun daya saing usaha ini bersifat dinamis oleh karena itu diperlukan dicermati halhal berikut agar daya saing tersebut tetap lestari.

Kondisi usaha yang bersifat padat karya yang diimplikasikan oleh kontribusi biaya tenaga kerjase besar $14 \%$ terhadap keseluruhan operasional usaha. Peningkatan permintaan kopi bubuk oleh konsumen yang terus meningkat mendorong pengusaha kopi bubuk meningkatkan suplai bahan baku sehingga membutuhkan kuantitas tenaga kerja yang lebih besar Peningkatan ini memperbesar penyerapan tenaga kerja oleh usaha ini seperti dikemukakan di atas. Ke depan peningkatan ini perlu diantisipasi secara cermat oleh usaha-usaha pengolahan kopi bubuk. Antisipasi dalam hal adanya kelangkaan pasokan beras kopi karena sebagian besar pedagang 
pengumpul dan petani terutama di Kabupaten Bengkulu Selatan dan Kaur menjual kopi beras ke pedagang antara daerah yang berasal dari Propinsi Lampung. Di sisi lain kelangkaan bahan baku disebabkan oleh penurunan produksi baik yang disebabkan oleh penurunan luas lahan tanam kopi maupun penurunan produktifitas hasil akibat pola budidaya yang masih tradisional seperti dikemukakan Hafsari (2005);Yuanda (2004) . Kurun waktu tertentu ketidakstabilan pasokan ini menyebabkan jumlah serapan tenaga kerja bersifat temporer sehingga akan berdamapk terhadap daya saing usaha.

Iklim usaha yang kodusif juga turut menentukan optimalitas perolehan pendpatan oleh para pelaku pengolahan kopi bubuk. Hal ini berarti idealnya izin usaha yang dimiliki mendorong kenyaman berusaha bagi pelaku usaha. Izin usaha dari depkes yang dimiliki pelaku usaha juga merupakan jaminan bahwa produk kopi bubuk yang dihasilkan berkualitas dan aman untuk dikonsumsi sehingga diharapkan dapat mendorong peningkatan konsumsi kopi yang sekaligus meningkatkan pendapatan mereka. Lokasi usaha menurut Romdhon et al (2004) yang strategis diyakini memberikan andil terhadap peningkatan perolehan pendapatan. Usaha-usaha kecil semacam ini umumnya berada di pusat-pusat perbelanjaan dan mudah dijangkau oleh konsumen terutama konsumen yang menggunakan jasa angkutan umum (angkot) maupun kendaraan pribadi. Namun beberap studi menunjukkan bahwa lokasi pengolahan kopi bubuk tidak memberikan pengaruh terhadap peningkatan pendapatan usaha (Romdhon,2005).

Kenaikan Bahan Bakar Minyak (BBM) perlu diantisipasi dampaknya terhadap keberlangsungan usaha serta perluasan usaha industri ini ke depan, meskipun kontribusi penggunaan BBM terhadap biaya produksi relatif kecil saat ini. Kenaikan harga BBM akan mendorong penurunan tingkat pendapatan usaha 


\section{DAFTAR PUSTAKA}

Anwar, A.(2002). Suatu Arah Tentang Analisis Institusi Sistem Kontrak Pertanian di Wilayah Perdesaan. Program Studi PWD, IPB. Bogor.

Coelli, T, D.S. Prasada Rao, and George E.Battese.(1998). An Introduction to Efficinecy and Productivity Analysis.Kluwer Academic Publisher Group. USA

Hayami, Y dan V.W.Ruttan.(1984). Agricultural Development, An International Perspective. The John Hopkin University Press, Baltimore and London.

Hafsari, S.E.(2004). Kontribusi dan Prospek Kopi Rakyat terhadap PDRB Subsektor Perkebunan di Propinsi Bengkulu. Seminar Akademik. FAPERTA UNIB.

Juita, E.(2004). Peranan Agroindustri dalam Perekonomian Kota Bengkulu. Seminar Akademik. Pertanian UNIB.

Pearson, Sjaiful Bahri, Gostch.(2003).

Romdhon, M,M et al (2004) Skala Usaha dan Pemasaran Industri Kecil Gula Aren dalam Sistem Ekonomi Kelembaaan Principle Agents di Kabupaten Rejang Lebong. Laporan Penelitian Hibah SP-4. Jurusan Sosial Ekonomi Pertanian. UNIB

Suryo Wardhani dan Herman.(2000). Perkembangan dan Prospek Komoditas Kopi. Tinjauan Komoditas Perkebunan (kelapa sawit, karet, gula, kopi, kakao dan teh) Vol.1 No.1 September 2000. Asosiasi Penelitian Perkebunan Indonesia dan Direktorat Jenderal Perkebunan.Bogor

Yuanda, Y.(2004). Studi Tentang Faktor-Faktor yang Mempengaruhi Perubahan Lahan Kopi di Propinsi Bengkulu. Skripsi.Jurusan SOSEK Pertanian UNIB.

Yusdja, Y dan Rosmiyati Sajuti.2002. Skala Usaha Koperasi Susu dan Implikasinya bagi Pengembangan Usaha Sapi Rakyat.JAE.hal 48n 63 Vol. 20 No.1 Mei 